\title{
Strength Assessment of wedges in the Splice Zone of the Column
}

\author{
Anirudh Joshi, Chaitanya Mishra
}

\begin{abstract}
Splice zone is the lower base of cross-section and a part of column which is also known as lower hinge zone. It is the weaker part of the column so additional reinforcement should be required every time in case of regular pad footing. The presented research provides a way of strengthening the reinforced concrete column by applying wedges at the splice zone. The work is focused on the base cross-section of an isolated footing against deflection, stresses, bending moment, etc. By implementing the proposed work, we can avoid critical damage at the base cross-section of the column \& it also provides more stability, thus make splice zone stronger than earlier to withstand the resistance. The two sets of footings are considered in which one is regular pad footing \& the other is pad footing strengthened by applying wedges in the splice zone. Both of them are tested under constant axial load and moment. The static structural analysis is done by using finite element analysis in ANSYS 2016 software. Further we will observe the deflection, stresses \& also the overall effects of applying wedges with multiple height \& size at the splice zone of the column.
\end{abstract}

Keywords: ANSYS, Base cross-section, bending moment, Finite element analysis, isolated footing, splice zone, wedge etc.

\section{INTRODUCTION}

In day to day life, it is essential to study \& monitor the behavior of each and every component of the structure because it varies greatly according to use, loading and end conditions of the various components. Columns are the most vital and compulsory component in any civil engineering structure which transfer all kind of load of the structure to the foundation. It plays significant role specially when building is tall and upcoming load is large. So, in the field of architecture and structural engineering " a column is a vertical structural component of any structure which transmits all kind of loads (Axial loads, moments, lateral load etc.) coming from above the floor \& also by the weight of structural elements i.e. beam, slab etc. It transfers the load in terms of compression effectively. So, we applied wedge having size of $450 \mathrm{~mm} \times 250 \mathrm{~mm} \& 625 \mathrm{~mm} \times 300 \mathrm{~mm}$ at the splice zone of the column \& then tested. Remaining all the dimensions was similar to the regular pad footing.

Revised Manuscript Received on October 20, 2020.

* Correspondence Author

Anirudh Joshi*, M. Tech, Department of Civil Engineering, Medi-Caps University, Indore (M.P.), India.

Prof. Chaitanya Mishra, Assistant Professor, Department of Civil Engineering, Medi-Caps University, Indore (M.P.)

(C) The Authors. Published by Blue Eyes Intelligence Engineering and Sciences Publication (BEIESP). This is an open access article under the CC BY-NC-ND license (http://creativecommons.org/licenses/by-nc-nd/4.0/)

\section{A. Literature Review}

Cem yalcin et al ${ }^{[01]}$ performed an experimental study on two RCC columns in which one was lap spliced and another one was having continuous reinforcement in the longitudinal direction.

CFRP sheet was applied by the surface of the column (lap spliced \& continuous reinforced) then constant axial and cyclic lateral load applied on that in both wrapped and unwrapped condition. It can be seen that the controlled column (continuous reinforced) with the FRP sheet gave significantly improved ductility and drift capacity than lap spliced columns.

Amlan K. SENGUPTAet al ${ }^{[02]}$ studied several techniques of retrofitting according to the desired condition and structural member of the structure. Each of them has its characteristics. It was divided into two groups' local retrofit \& global retrofit. The local retrofit includes beam, column, slab, beam to column joint, foundation, walls, etc.

M.Sarafraz et al ${ }^{[03]}$ observed that column end plastic hinge regions strength can be augmented by a combination of "Near-surface mounted rods \& fiber reinforced polymer jacketing" for the confinement of concrete \& prevention against seismic overturning. They placed NSM rods in the holes (filled with epoxy) in appropriate position on the beam, footing, slab, etc along the required direction. FRP jacketing is also provided onto the required surface. Results show that the NSM rod can increase the flexural rigidity of the RCC columns.

E.choi et al ${ }^{[04]}$ performed several tests on the bottom hinge portion of the column by using SMA "Shape memory alloy". They used NiTi SMA Wire \& NiTiNb SMA wire. Both shows shape memory effect and gave active confinement for concrete. This SMA wire is prestrained around the lower hinge of a column. Then they increase the temperature by heating so we get the confined section of the RCC column. Thus, the ductility will increase of the splice zone of the RCC column.

Bassem Andrawes et al ${ }^{[05]}$ studied from previous earthquake experiences that there is a need to improve the reinforcement in a lateral direction at the bottom of the column to improve the ductile strength of concrete column employing "Shape memory alloy" [SMA] against seismic behavior of bridges column. SMA can be used for both, circular as well as rectangular/ square-shaped columns $\&$ it is more efficient than FRP jackets. They used "SMA" from outside and then further stressed it by prestressing to improve the load-carrying capacity. This technique resulted effective in restoring and strengthening the splice zone.
Blue Eyes Intelligence Engineering and Sciences Publication

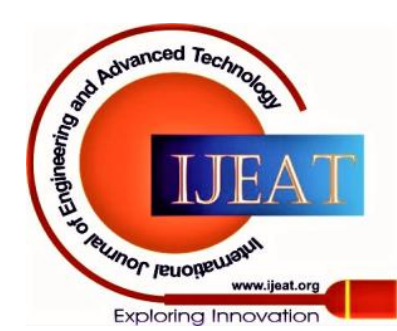




\section{Strength Assessment of wedges in the Splice Zone of the Column}

Jianhua Liu et al ${ }^{[06]}$ studied the development of efficient columns by strengthening through steel collars externally for the confinement of the column.

It helps to achieve more flexural \& axial strength of the column and ultimately, we can get column having more ductility. An experimental study was conducted.

Parameters considered in the experimental program were collar spacing, collar stiffness, longitudinal reinforcement ratio, the pretension of collar bolts, axial compression ratio, etc. It resulted that for the specimen of the same size and reinforcement, collared reinforced concrete columns resisted more force \& ductility.

Dario Rosignoli et al ${ }^{[07]}$ used concrete jacketing to increase the strength in seismic retrofitting. This technique generally used for the RCC column of a lower grade. They took column with a $16 \times 16$ inch $(400 \times 400 \mathrm{~mm})$ square cross-section and $3000 \mathrm{~mm}$ in height. A thin high-performance fiber-reinforced concrete coating applies of about 1 to 1.6 inch (30 to $40 \mathrm{~mm}$ ) thick up to $1200 \mathrm{~mm}$ height. Thus, the strength of the existing RCC column significantly increased and also gave a result similar to the other jacketing techniques (FRP, Steel jacketing).

A.M. Tarabia et al ${ }^{[08]}$ studied that the efficiency and durability of square RCC columns can be increased by providing steel angle \& strips (steel cage) against the axial load. Size of the steel angles, strip spacing, grout material (cement grout or epoxy grout) between column sides and angles, and the connection between the steel cage to the specimen head, efficiency and behavior of reinforced concrete columns were the main parameters studied in this paper. Vertical angle and horizontal strips were kept together by welding. It was concluded that using this method axial load capacity was effectively increased and it was also noticed that axial load carrying capacity of the strengthened column increased by $50 \%$ in most cases compared to that of the unstrengthened columns. The axial capacity also increased by 35 to $110 \%$.

Mostafa fakharifar et al [09] studied a hybrid jacketing technique for strengthening the seismically damaged reinforced concrete column in a bridge. They used a thin cold-formed steel sheet wrapped from outside (along the column perimeter) and further confined by prestressing of strands. Hybrid jacketing technique results were very effective in restoring and strengthening the splice zone of a column at just above the footing.

ZumrawiM. M.E. \& AldawH. K.E ${ }^{[10]}$ in their review paper took a case study in which they observed that story extension can be done in any existing structure by adopting some foundation strengthening techniques, whenever story extension is required. In this technique dimensions were increased by drilling holes in the existing footing pad and filling those with epoxy grouting, then additional reinforcement was done around the footing. Additional concreting was done of thickness $100 \mathrm{~mm}$. They studied that after the strengthening of footing it was capable to carry the additional extra load of the building.

Asma Nabila binti et al ${ }^{[11]}$ observed that Many researchers have proposed experimental and analytical solutions to understand beam-column joint behavior. Generally, techniques "near-surface mounted \& glass fiber reinforced polymer" [NSM \& GFRP] used for beam-column joints to provide strength. This is done by simply applying a coating over the epoxy-based mortar at the lower portion of the beam. After that apply carbon fiber reinforced polymer CFRP sheet covering in a longitudinal direction. Wrapping of anchorage strip is done at the lower portion of the beam. Similarly, the GFRP technique is used for the exterior portion of the beam-column joint. The use of CFRP wrap resulted in a higher increase in the strength, while the GFRP wrap can result in an appreciable increase in strength with the advantages of lower cost and higher chemical resistance.

\section{B. Objectives}

This study is focused on the pad footing \& its overall behavior after the application of the wedges in the splice zone of the column (At the footing level). So, the objectives of the study are as follows:

1. To do a comparative study between the pad footing with the pad footing after applying wedges at the splice zone

2. To minimize the overall cost of the footing.

3. To reduce the bending moment at the splice zone or base cross-section of the column.

4. To reduce the deflections of the column.

5. To reduce the stresses of the footing.

6. To increase the strength of the column against all kind of load \& stresses.

\section{METHODOLOGY}

In this work for the analysis of the pad footing we have used the finite element method for the determination of deflection \& stresses. So, we used CATIA V5R16 to model the isolated footing. The percentage of the reinforcement \& arrangement of the rebar will be changed with every increase in the height of the wedge. Loading \& boundary conditions were also similar in both the models. For the determination of the bending moment, we made a 1D model using design modular in ANSYS then analyzed. We have used ANSYS Software to avoid lots of hand calculation to calculate deflection \& stresses over the footing. The computation is done over ANSYS version 16.0.

Following steps are adopted during the study:

1. For the computation, Workbench needed to be open in ANSYS software version 16.0.

2. Static structural should be selected in the analysis system from the toolbox which is on the left-hand side of the window.

3. We can add various types of material and can change the properties of any material as per our requirement.

4. Model for the analysis has been imported which is made in CATIAV5R16. After importing of model, mechanical application is opened by clicking on the model module. When the workbench opens it automatically attaches the geometry itself.

The steps involved in the mechanical application are given below:

a. First, the material is assigned to the geometry imported that is concrete \& steel.

Published By:

Blue Eyes Intelligence Engineering and Sciences Publication

(C) Convriaht: All riahts reserved. 
b. After this, the mashing details and size i.e. $150 \mathrm{~mm}$ have to be given to the software.

c. In the next step, the boundary conditions are provided as fixed support at the base of the footing.

d. After this, the axial load applied at top of the column \& moment at the faces of the column.

e. In the final step solution required is inserted, and then software runs the analysis and gives the results.

Properties of the material used in footing is given below

\section{- Dimensions of the footings}

Length of the footing $=1200 \mathrm{~mm}$

Width of the footing $=1200 \mathrm{~mm}$

Thickness of the footing $=450 \mathrm{~mm}$

Length of the column $=300 \mathrm{~mm}$

Width of the column $=300 \mathrm{~mm}$

Height of the column $=3000 \mathrm{~mm}$

- Material properties of concrete used in footings

Density $=2300 \mathrm{~kg} / \mathrm{m}^{3}$

Poisons ratio $=0.18$

Young's modulus $=30000 \mathrm{MPa}$

Tensile ultimate strength $=5 \mathrm{MPa}$

Compressive ultimate strength $=41 \mathrm{MPa}$

- Material properties of steel used in footings

Density $=7850 \mathrm{~kg} / \mathrm{m}^{3}$

Poisons ratio $=0.3$

Young's modulus $=200000 \mathrm{MPa}$

Tensile yield strength $=250 \mathrm{MPa}$

Compressive yield strength $=250 \mathrm{MPa}$

Tensile ultimate strength $=460 \mathrm{MPa}$

Compressive ultimate strength $=0$

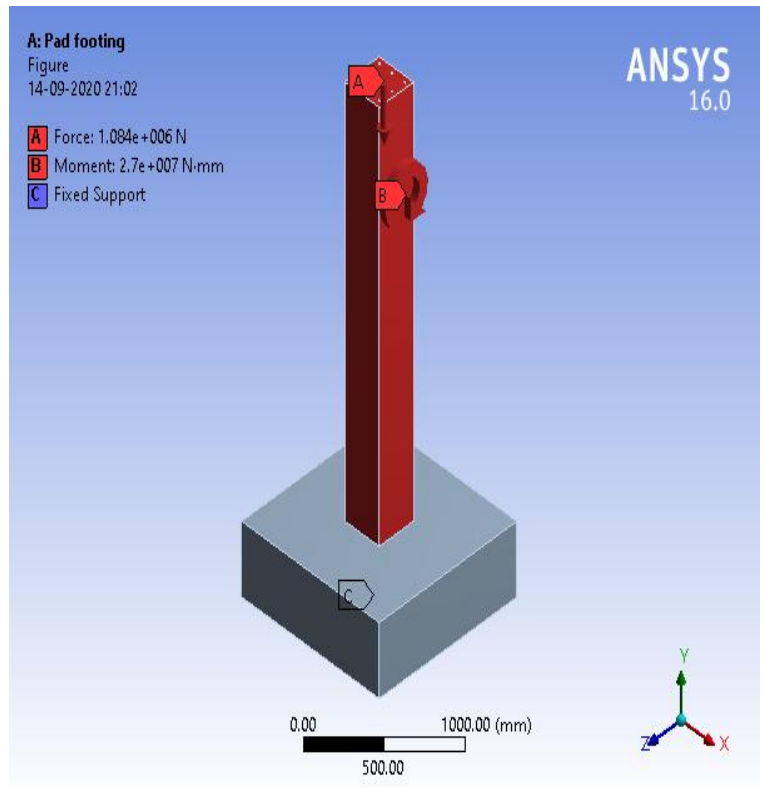

Fig.1 Boundary conditions for pad footing in ANSYS Workbench

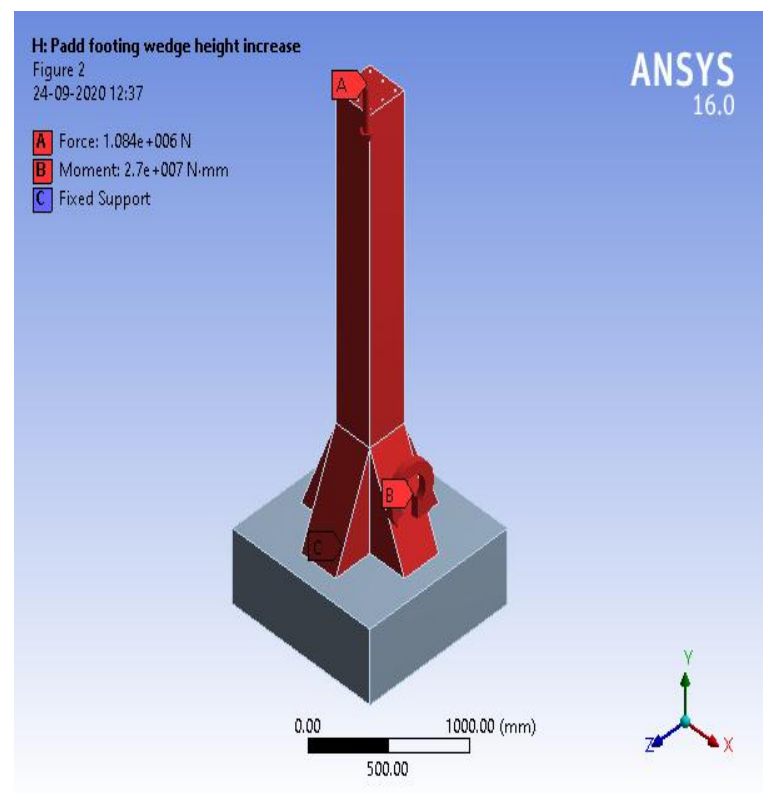

Fig.2 Boundary conditions for pad footing after applying wedges in ANSYS Workbench

\section{RESULTS AND DISCUSSION}

General: All the solutions were obtained from the analysis through ANSYS. In the pictures, blue color represents the minimum deflection area while the maximum deflection area is representing by red color. The graphs are also plotted for the pad \& after applications of varying sizes of wedges at the splice zone. The results we got from the analysis are as follows:

1) Total deformation in geometry.

2) Equivalent stress in geometry.

3) Bending moment in pad footing.

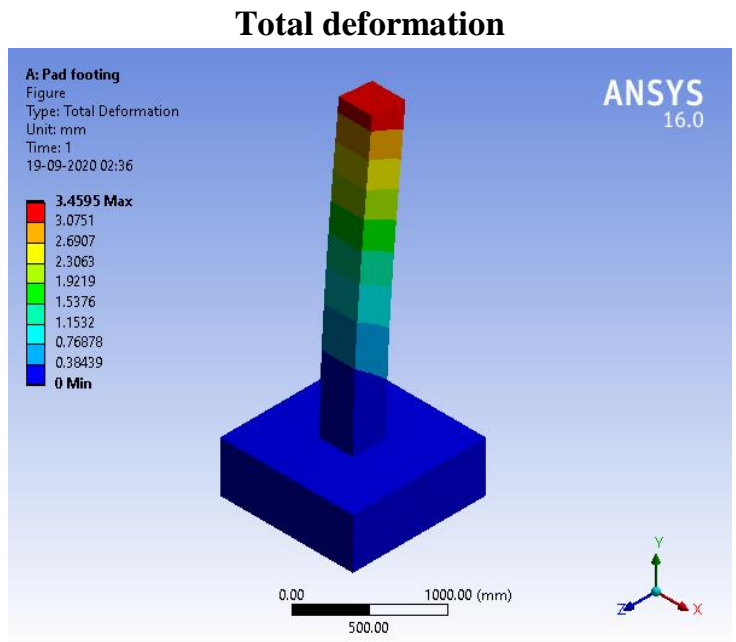

Fig. 3 Total deformation in Pad footing

Published By:

Blue Eyes Intelligence Engineering and Sciences Publication

(C) Copyright: All rights reserved.

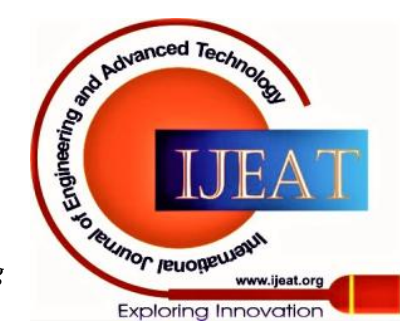




\section{Strength Assessment of wedges in the Splice Zone of the Column}

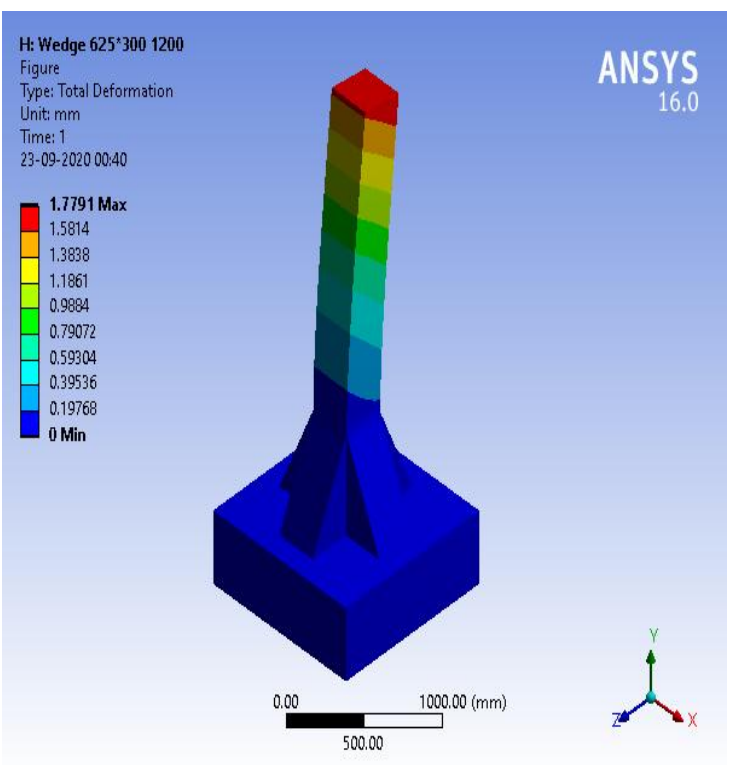

Fig. 4 Total deformation in pad footing after application of wedges

As per study \& analysis, maximum deformation found in pad footing as $3.4595 \mathrm{~mm}$ while in the same pad footing after applying wedges at the splice zone, the total deformation is found less i.e. $1.7791 \mathrm{~mm}$. This means that it shows better stability against loading and also having minimum deformation after applying wedges than both the regular pad footing.

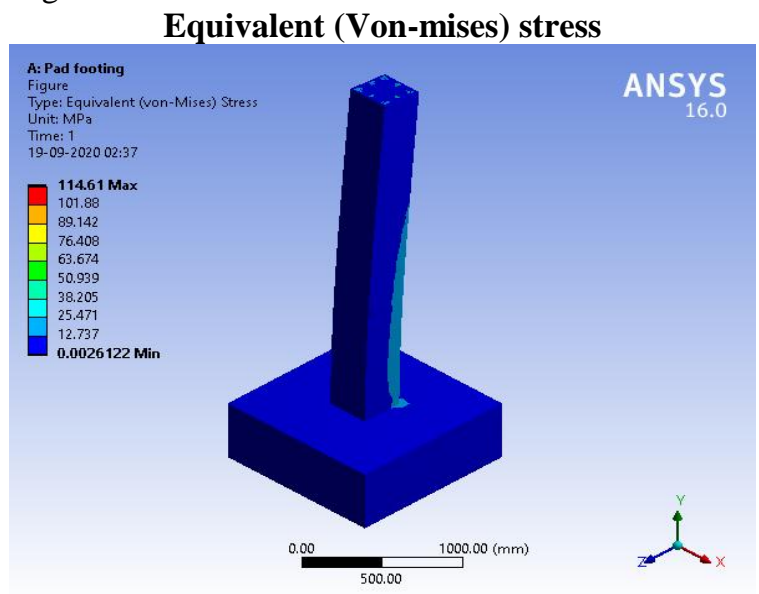

Fig. 5 Equivalent von-misses stress for pad footing

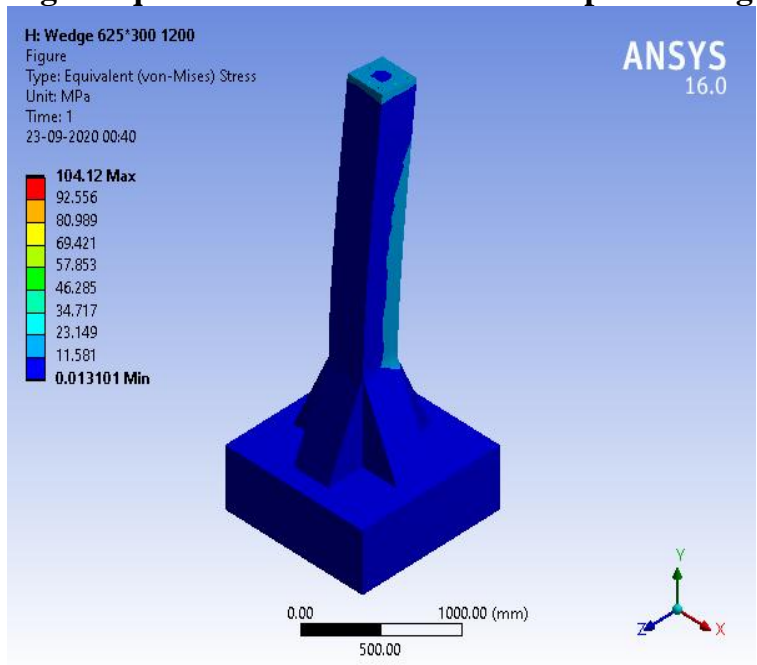

Fig. 6 Equivalent von-misses stress for pad footing after application of wedges

Equivalent stress found maximum in pad footing as 114.61
MPa. While in the same pad footing after applying wedges at the splice zone, the equivalent stress is found less i.e. 104.12 $\mathrm{MPa}$. The results shown here prove that equivalent stress reduce as increase in the height of the wedge.

\section{Bending moment in pad footing}

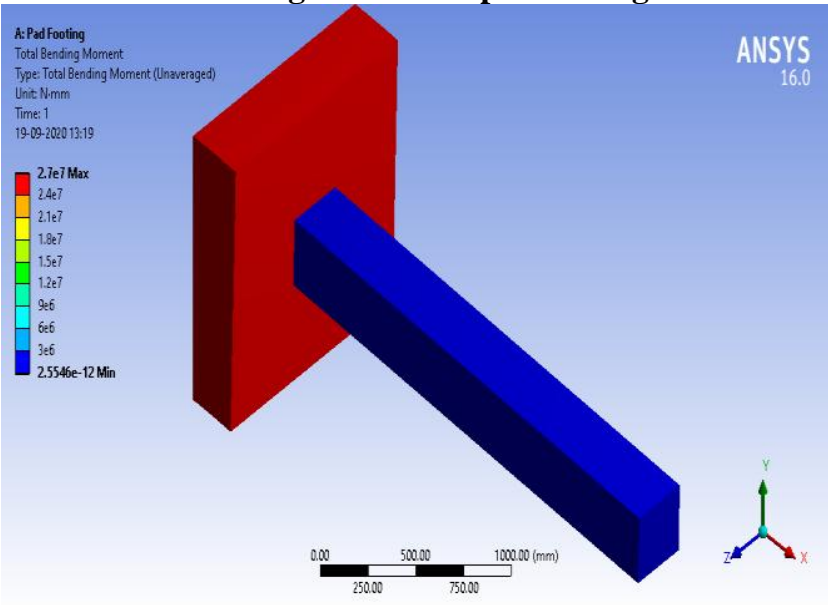

Fig. 7 Bending moment for pad footing

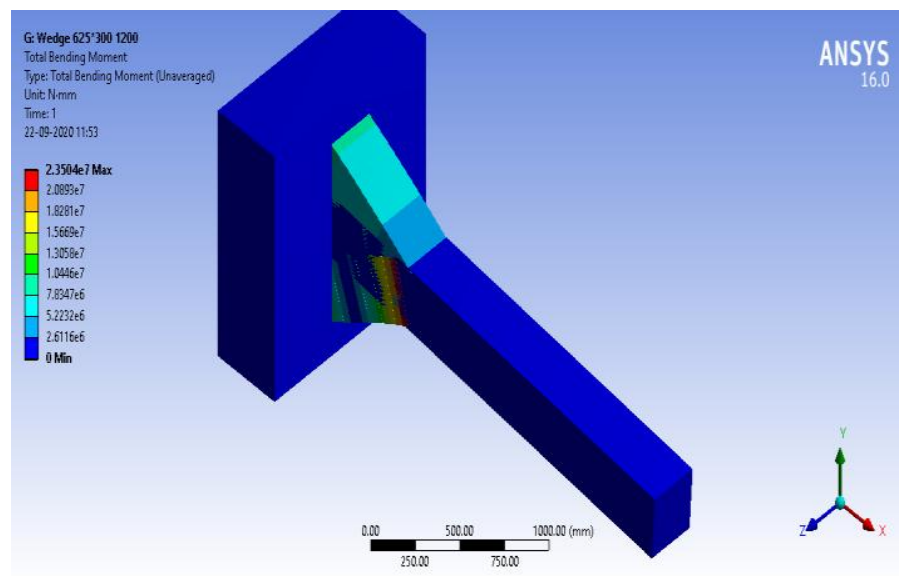

Fig. 8 Bending moment for pad footing after applying wedges

The maximum bending moment was found in the pad footing as $2.7 \mathrm{e}+007 \mathrm{~N} \cdot \mathrm{mm}$ while after applying wedges in the same footing its reduced up to $2.3504 \mathrm{e}+007 \mathrm{~N} \cdot \mathrm{mm}$. So in other words we conclude that after application of the wedge bending moment will reduce. Also, it will decrease more with increase in height of the wedge.

Table 1: Stress and deformation in footings

\begin{tabular}{|c|c|c|c|}
\hline $\begin{array}{c}\text { Isolated } \\
\text { footing }\end{array}$ & $\begin{array}{c}\text { Total } \\
\text { Deflection } \\
(\mathrm{mm})\end{array}$ & $\begin{array}{c}\text { Equivalent } \\
\text { stress }(\mathrm{MPa})\end{array}$ & $\begin{array}{c}\text { Bending } \\
\text { Moment } \\
{[\mathrm{N} \cdot \mathrm{mm}]}\end{array}$ \\
\hline Pad Footing & 3.4595 & 114.61 & $2.70 \mathrm{E}+07$ \\
\hline $\begin{array}{c}\text { Pad footing } \\
\text { with Wedge } \\
425 \times 250\end{array}$ & 2.2151 & 106.5 & $2.54 \mathrm{E}+07$ \\
\cline { 1 - 2 } $\begin{array}{c}\text { Pad footing } \\
\text { with Wedge } \\
625 \times 300\end{array}$ & 1.7791 & 104.12 & $2.35 \mathrm{E}+07$ \\
\hline
\end{tabular}

Published By:

Blue Eyes Intelligence Engineering and Sciences Publication

(C) Convriaht: All riahts reserved.

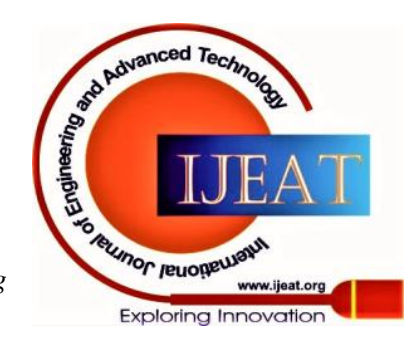




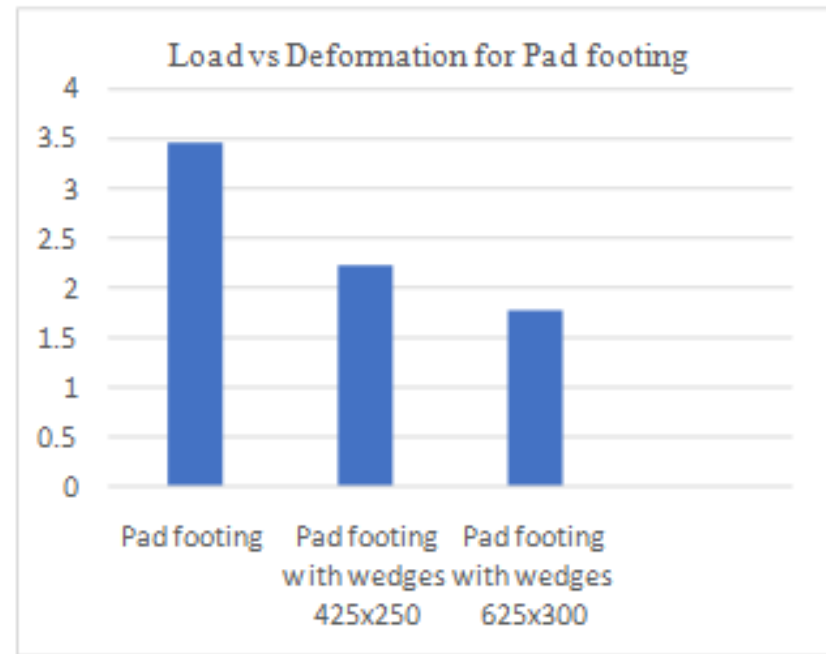

Graph 1: Load vs. Deformation comparison for pad footing

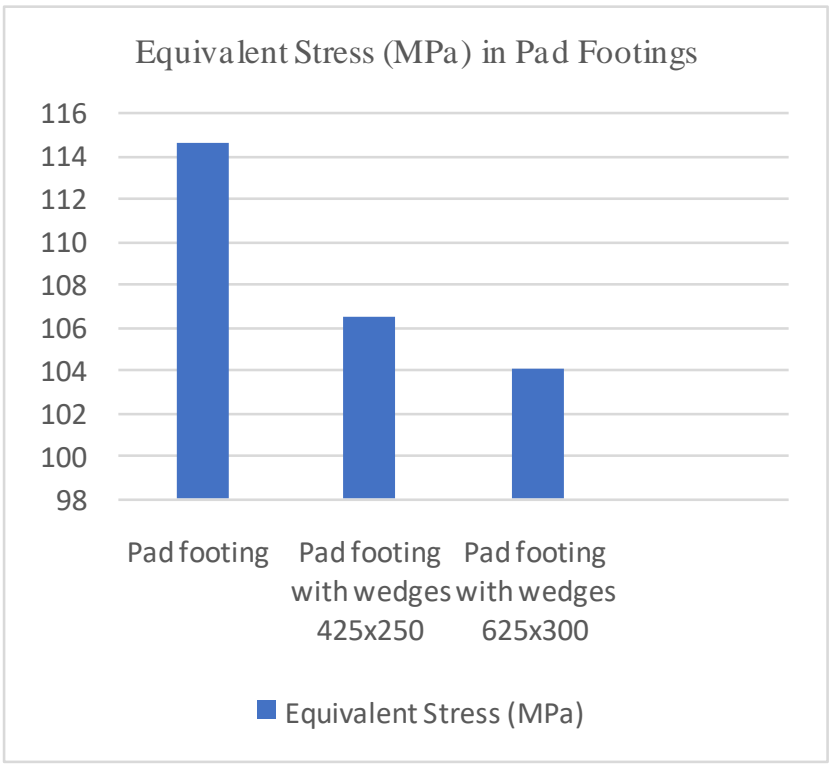

Graph 2: Equivalent Stress Comparison for pad footing

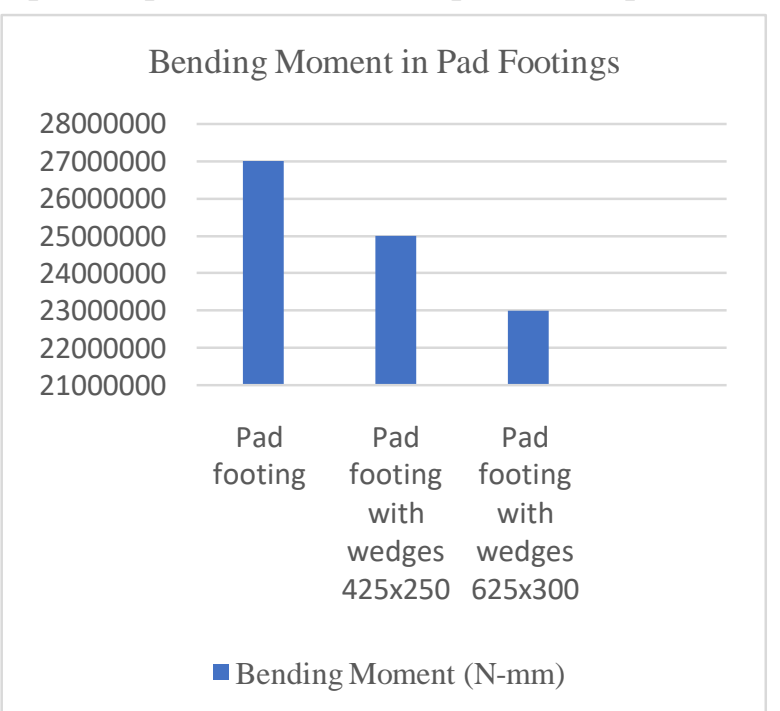

Graph 3: Bending Moment comparison for pad footings

\section{CONCLUSION}

The behavior of the tested columns with and without wedges, against axial load and moment are derived and analysed. A static structural model is developed by using ANSYS 16.0 software. The arguments such as deformation/deflection, equivalent stress \& bending moment etc are considered for the reinforced concrete column. Although the failure loads have not been truly determined, therefore the highest analyzed load which is applied may be considered as the ultimate load for the model. Based on the comparison of results, the following conclusions are drawn:

1. Pad footing with the wedges (Fig. 2) have better performance than conventional pad footing (Fig. 1) as there is no need to provide any extra reinforcement at the splice zone.

2. It has been observed that deflection or deformation is also decreased after applying the wedges in pad footing. The wedge of size $425 \mathrm{~mm} \times 250 \mathrm{~mm}$ has reduced the deflection upto $35.97 \%$ and the wedges of size $625 \mathrm{~mm} \mathrm{x}$ $300 \mathrm{~mm}$ has additionally reduced it upto $48.57 \%$. (Fig. 4) Ultimately, this will increase the overall performance \& durability of the footing.

3. Stresses are minimized in footings provided with wedges \& also gets distributed more effectively than conventional footings. The wedges of pad footing having size $425 \mathrm{~mm}$ x $250 \mathrm{~mm}$ has an equivalent stress minimized by $7.07 \%$. On increasing the size of wedges to $625 \mathrm{~mm} \mathrm{x}$ $300 \mathrm{~mm}$ the stress gets more minimized by $9.15 \%$. (Fig. 6)

4. Bending moment is reduced in the pad footing (Fig. 7) after applying the wedges of size $425 \mathrm{~mm} \times 250 \mathrm{~mm}$ by $5.97 \%$ and further it gets reduced by applying wedges of size $625 \mathrm{~mm} \times 300 \mathrm{~mm}$ by $12.94 \%$. (Fig. 8)

5. Results show that the column after strengthening by wedges is capable to carry extra load and the effectiveness of the wedge application has increase the performance in terms of ductility.

\section{ACKNOWLEDGEMENTS}

I would like to express a deepest sense of gratitude to all the scholars, authors and publishers whose articles, research and journals are cited and valuable data was reviewed and discussed for completing this study. I also want to express my heartfelt gratitude to my guide \& university, who has provided me every facility \& for continuous help \& support.

\section{REFERENCES}

1. Cem YALÇIN and Osman KAYA.” An experimental study on the behavior of reinforced concrete columns using FRP material". 13th World Conference on Earthquake Engineering, Vancouver, B.C. Canada, August 1-6, 2004 paper no 919.

2. Amlan K. SENGUPTA, CHEMURU Srinivasulu Reddy, Badari Narayanan V T and Asokan "Seismic Analysis and retrofit of existing multistoried building in India - An overview with a case study". 13th World Conference on Earthquake Engineering, Vancouver, B.C., Canada, August 1-6, 2004 paper no. 2571

3. M.Sarafraz and F.Danesh. "Flexural enhancement of RC columns with FRP”. The 14th World Conference on Earthquake Engineering, October 12-17, 2008, Beijing, China.

Published By:

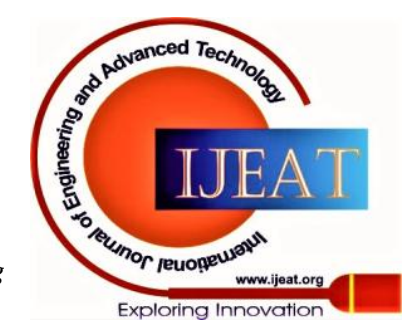




\section{Strength Assessment of wedges in the Splice Zone of the Column}

4. E.Choi, K.T. Yang, G.H. Tae, T.H. Nam and Y.S. Chung. "Seismic retrofit for RC columns by NiTi and NiTiNb SMA Wires". ESOMAT 2009, 07005 (2009), DOI:10.1051/esomat/200907005, owned by the authors, published by EDP science, 2009.

5. Bassem Andrawes, Qiwen Chen and Moochul Shin. "New SMA Confinement technology for RC bridge column".

6. Jianhua Liu, Robert G. Driver, and Adam S. Lubell. "Experimental Study on Short Concrete Columns with External Steel Collars". ACl Structural Journal/May-June 2011, Title no. 108-S35

7. Dario Rosignoli, Francesca Simonelli, Alberto Meda, and ROberto Rosignoli. "High-Performance Fiber-Reinforced Concrete Jacketing in a Seismic Retrofitting Application". Concrete Repair Bulletin, September/October 2012 ( www.icri.org )

8. A.M. Tarabia and H.F. Albakry. "Strengthening of RC columns by steel angle sand strips". Department of Structural Engineering, Alexandria University, Alexandria, Egypt Received 4 March 2014; revised 2 April 2014; accepted 15 April 2014 available online in 17 may 2014. Alexandria engineering journal (2014) 53, 615, 626

9. Mostafa Fakharifar, Genda Chen, Mahdi Arezoumandi, and Mohamed ElGawady. "Hybrid Jacketing for Rapid Repair of Seismically Damaged Reinforced Concrete Columns". Article in Transportation research record: Journal of the Transportation Research Board, 2522, Transportation Research Board, Washington D.C., 2015 pp. 70-78. DOI: $10.3141 / 2522-07$

10. Zumrawi M. M. E. and Aldaw H. K. E. "A study on Strengthening of Building foundation for Storey Extension”. J. Build. Mater. Structure. (2018) 5: 218-226 DOI: 10.5281/zenodo.2538661, ISSN 2353-0057, EISSN: 2600-6936

11. Asma Nabila binti Abd Kader, S. A. Osman, and M. Y. M. Yatim. "A state-of-the-art review on retrofitting beam column joint using GRPF with NSM techniques under seismic loading". International Journal of Engineering and Technology, Vol. 11, No. 1, February 2019

12. Design of RCC structures by SS Bhavikatti, Third Edition,2016, pp 34

13. Indian standard code IS 456:2000

14. Indian standard code IS $13920: 1993$

15. Indian standard code IS 800:2007

16. https://en.m.wikipedia.org/wiki/Ansys

\section{AUTHORS PROFILE}

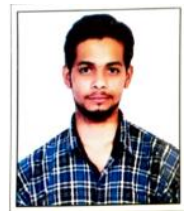

Anirudh Joshi had completed his Bachelors of Engineering from Vindhya Institute of Technology, RGPV University Bhopal. At present, he is pursuing M. Tech (Structural Engineering) in Civil Engineering from Medi-Caps University, Indore (M.P.)

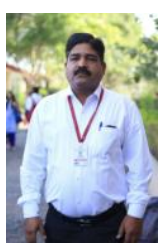

Prof. Chaitanya Mishra completed M.E. from SGSITS, Indore. At present, he is working as Assistant Professor, Department of Civil Engineering, Medi-Caps University, Indore (M.P.)

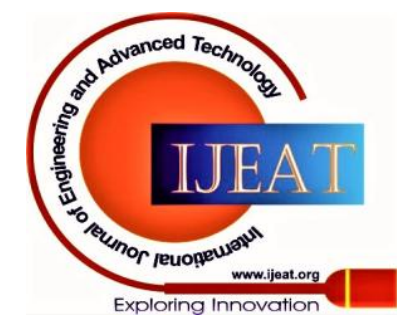

